\title{
Prehospital hjerneslagbehandling - tid er hjerne
}

\author{
Ved akutt behandling av hjerneslag er tiden avgjørende for utfallet. Dagens retningslinjer medfører et tidstap \\ som begrenser mulighetene for effektiv behandling. For å redde liv og helse må prehospitale tiltak inngå \\ som en aktiv del av behandlingskjeden. Luftambulansene bør utstyres med CT-skanner med telemedisinsk \\ overføring av CT-bilder for diagnostikk utført i nærmeste slagenhet.
}

Årlig rammes om lag 15000 nordmenn av hjerneslag, og tallet vil øke med $50 \%$ de neste 20 år på grunn av en aldrende befolkning. Hjerneslag er tredje hyppigste dødsårsak her i landet (1). I 2010 døde 3180 personer av hjerneslag, til sammenlikning døde 3340 av hjerteinfarkt (2). Dersom livet ikke går tapt, vil mange få varige og betydelige sekveler.

$85-90 \%$ av hjerneslagene er hjerneinfarkter der en trombe okkluderer en cerebral arterie og forårsaker iskemisk skade i arteriens distale forsyningsområde (3). De resterende $10-15 \%$ er hjerneblødninger. Kun ved hjelp av bildediagnostikk, i form av CT- eller MR-undersøkelse, kan man skille mellom hjerneinfarkt og hjerneblødning.

Ved hjerneinfarkt må årsaksrettet behandling, dvs. reetablering av lokal cerebral sirkulasjon, iverksettes så raskt som mulig fordi det ofte foreligger et reversibelt iskemisk affisert område (penumbravolumet) de første timene etter infarktet. Årsaksrettet behandling er medikamentell intravenøs trombolyse, invasiv fjerning av den okkluderende tromben eller en kombinasjon av disse. For hjerneblødning kan årsaksrettet behandling bety akutt nevrokirurgisk intervensjon. Tapet av hjerneceller ved cerebral iskemi er estimert til ca. 1,7 millioner hjerneceller per minutt (4). Effekten av reperfusjon avtar raskt over tid, mens komplikasjonsfaren øker (5). Etter 240-300 minutter fra symptomdebut vil den positive effekten av reperfusjon nærme seg null $(5,6)$. Andelen hjerneinfarktpasienter som vil oppleve nytte av trombolytisk behandling, avtar dramatisk med antall minutter fra symptomdebut.

\section{De nasjonale retningslinjene}

Dagens nasjonale retningslinjer forutsetter at årsaksrettet hjerneslagbehandling er intrahospital, basert på bildeundersøkelse av hjernen foretatt etter innleggelse i sykehus. Intravenøs trombolytisk behandling skal utføres i regi av sykehusets slagenhet, invasiv trombektomi ved spesialiserte slagenheter ved universitetssykehusene og nevrokirurgisk intervensjon ved nevrokirurgiske avdelinger (1).

Om den prehospitale håndteringen skrives det: «Rask identifikasjon av pasienter med akutt hjerneslag og umiddelbar innleggelse i sykehus med slagenhet er viktig for å kunne tilby optimal akutt behandling inkludert trombolyse (nivå 1a). (...) Dersom fastlege/legevakt eller andre instanser i helsetjenesten er de som først blir kontaktet ved et mistenkt tilfelle av akutt hjerneslag er den viktigste oppgaven å medvirke til rask innleggelse, ev. uten forutgående undersøkelse, da en slik undersøkelse ofte vil kunne forsinke innleggelse» (1).

Helseministerens ambisjon er at $20 \%$ av pasientene med hjerneinfarkt skal få intravenøs trombolytisk behandling før det har gått 270 minutter fra symptomdebut. Kun få sykehus er i nærheten av å innfri

\section{«For å kunne oppnå virkelig klinisk nytte av aktiv rekanalisering ved hjerneinfarkt er de første 90 minuttene avgjørende»}

dette målet, og landsgjennomsnittet ligger på rundt $5 \%$. Det er store forskjeller i trombolysefrekvens, dvs. hvor mange pasienter som får årsaksrettet behandling. I 2011 innførte Helsedirektoratet trombolysefrekvens ved hjerneinfarkt som en «nasjonal kvalitetsindikator» (7).

Det er en rekke forklaringer på de lave og sprikende tallene. Pasientene kjenner ikke symptomene på hjerneslag og eller de venter med å varsle, legevaktsentralene og AMK-sentralenes prioritering av henvendelser kan variere, og de geografiske og demografiske forhold her i landet gjør at det med dagens retningslinjer er vanskelig å tilby årsaksrettet behandling i tide. En desentralisert sykehusstruktur med variabel intramural fagkompetanse bidrar til at behandlingstilbudet blir forskjellig.

\section{Prehospital hjerneslagbehandling}

For å kunne oppnå virkelig klinisk nytte av aktiv rekanalisering ved hjerneinfarkt er de første 90 minuttene avgjørende (5). Hvor mange som må behandles for at én skal få bedret utfall (numbers needed to treat, NNT) etter behandling med intravenøs rekombinant human vevsplasminogenaktivator (r-tPA, alteplase) er rapportert å være $<4$ innenfor 90 minutter, men hele 45 ved 271-360 minutter (5).

Trombolytisk behandling av hjerteinfarkt ble innført i Norge tidlig i 1990-årene (8). På tilsvarende måte som da må man ved akutt hjerneslag ta i bruk det prehospitale rom for diagnostikk, høykvalitetstriage og årsaksrettet behandling. Men selv om patogenesen er tilnærmet lik ved hjerte- og hjerneinfarkt, finnes det vesentlige diagnostiske og terapeutiske forskjeller som gjør at 1990-årenes erfaringer ikke er direkte overførbare. Prehospital behandling av cerebral iskemi er helt avhengig av presis diagnostisk differensiering mot cerebral blødning. Videre må det ved akutt cerebral iskemi avklares om det foreligger en proksimal eller en distal arterieokklusjon, for dermed å kunne velge ut dem som bør behandles med invasiv teknikk.

Selv om videreutvikling av dagens diagnostiske verktøy er tuftet på at hjerneslagbehandlingen foregår i sykehus (in-hospital), pågår det et forsknings- og utviklingsarbeid innen prehospital diagnostikk basert på biomarkører (9), mikrobølger (10), infraskanning (11) og ultralyd (12). Likevel er det diagnostikk på grunnlag av bildeundersøkelse av hjernen som har det største potensialet prehospitalt. Walters og medarbeidere har vist at $\mathrm{i}$ et område med kort avstand til sykehus kan tiden fra symptomdebut til trombolytisk behandling reduseres til $<90$ minutter ved hjelp av ambulanse utstyrt med CTskanner og bemannet med nevrolog og nevroradiolog (13). Til sammenlikning tok rask transport til slagpost for diagnostikk og trombolytisk behandling $>150$ minutter. Videre viste man at ikke bare hjerneslagpasientene, men alle undersøkte pasienter ble raskere og riktigere triagert, med raskere spesifikk årsaksrettet behandling som resultat $(13,14)$.

Det er vanskelig å tenke seg at ambu- 
lanser bemannet med nevrolog og nevroradiolog kan bli mulig i Norge. Dessuten har en bakkebasert mobil slagenhet begrenset dekningsområde. Men det tyske prosjektet viste tydelig at telemedisinsk overføring av CT- bilder for parallell diagnostikk gjort i sykehusets slagenhet er mulig (13).

I Norge har vi en godt utbygd anestesilegebemannet luftambulansetjeneste, som med adekvat diagnostisk verktøy og bruk av intravenøse trombolytika vil kunne minimere tiden fra symptomdebut til årsaksrettet behandling for et stort antall hjerneslagpasienter. Dette forutsetter telemedisinsk diagnostisk støtte fra et nevrologisk og nevroradiologisk fagmiljø og gode prosedyrer for triagering av pasienter til intervensjonsbehandling eller nevrokirurgi. Luftambulansen har maksimum reaksjonstid (tid fra alarm til avgang) på 15 minutter og kan nå størstedelen av befolkningen innen 30 minutter. Ved rask varsling er det realistisk å iverksette trombolytisk behandling og/eller transport av pasient direkte til invasiv behandling innen 90 minutter fra sykdomsdebut.

Stiftelsen Norsk Luftambulanse (SNLA) arbeider med å tilpasse en CT-enhet til dagens luftambulanseflåte og utarbeider prosedyrer for prehospital årsaksrettet hjerneslagbehandling. Videre planlegges en multisenterstudie om prehospital diagnostikk og trombolytisk behandling ved hjerneinfarkt. I denne studien vil det bli benyttet bakkebaserte CT-utstyrte ambulanser bemannet med anestesiolog og spesialsykepleier. Studien inngår i et større europeisk forskningssamarbeid.

Ved hjerneslag er tiden til årsaksrettet behandling helt avgjørende for utfallet.
Behandlingstilbudet må styres av hensynet til tid fremfor hensynet til sykehusenes organisering. Ved å inkludere det prehospitale rom i behandlingskjeden vil helseministerens ambisjoner kunne løftes betraktelig - til hjerneslagpasientens fordel.

\section{Hans Morten Lossius}

hans.morten.lossius@norskluftambulanse.no Christian Georg Lund

Hans Morten Lossius (f. 1959) er spesialist i anestesiologi, professor i prehospital avansert akuttmedisin ved Universitetet i Stavanger Han leder forsknings- og utviklingsavdelingen i Stiftelsen Norsk Luftambulanse. Forfatter har fylt ut ICMJE-skjemaet og oppgir ingen interessekonflikter.

Christian Georg Lund (f. 1961) er dr.med., spesialist i nevrologi og overlege ved Nevrologisk avdeling, Oslo universitetssykehus, Rikshospitalet. Han har de siste årene særlig arbeidet med å introdusere aktiv revaskularisering ved akutt hjerneinfarkt.

Forfatter har fylt ut ICMJE-skjemaet og oppgir ingen interessekonflikter.

\section{Litteratur}

1. Behandling og rehabilitering ved hjerneslag Nasjonale retningslinjer. Oslo: Helsedirektoratet. 2010.

2. Statistikkbanken. http://statbank.ssb.no/ statistikkbanken/ (10.7.2012)

3. Dahl A, Lund C, Bjørnstad A et al. Cerebrovaskulære sykdommer. I: Gjerstad L, Helseth E, Rootwelt T, red. Nevrologi og nevrokirurgi fra barn til voksen. Oslo: Forlaget Vett \& Viten, 2010: 41-59.

4. Saver JL. Time is brain - quantified. Stroke 2006; 37: $263-6$.
5. Hacke W. Donnan G. Fieschi C et al. Association of outcome with early stroke treatment: pooled analysis of ATLANTIS, ECASS, and NINDS rt-PA stroke trials. Lancet 2004; 363: 768-74.

6. Hajjar K, Kerr DM, Lees KR. Thrombolysis for acute ischemic stroke. J Vasc Surg 2011; 54: $901-7$.

7. Helsedirektoratet. Nasjonale kvalitetsindikatorer N-016: Trombolysebehandlinger. http://nesstar2.shdir.no/kvalind/ (10.7.2012).

8. Lossius HM, Wisborg T, Gunnarson E et al. Prehospital trombolytisk behandling av hjerteinfarkt i Nord-Norge. Hvordan forbedre tilbudet til befolkningen i tynt befolkede områder? Tidsskr Nor Lægeforen 1995: 115: 1961-3.

9. Foerch C, Niessner M, Back T et al. Diagnostic accuracy of plasma glial fibrillary acidic protein for differentiating intracerebral hemorrhage and cerebral ischemia in patients with symptoms of acute stroke. Clin Chem 2012; 58: 237-45

10. Khorshidi MA, McKelvey T. Persson M et al. Classification of microwave scattering data based on a subspace distance with application to detection of bleeding stroke. I: Institute of Electrical and Electronics Engineers, red. 3rd IEEE International Workshop on Computational Advances in MultiSensor Adaptive Processing (CAMSAP). Aruba, De nederlandske Antiller: CAMSAP, 2009: 301-4

11. Leon-Carrion J, Dominguez-Roldan JM, LeonDominguez $U$ et al. The Infrascanner, a handheld device for screening in situ for the presence of brain haematomas. Brain Inj 2010; 24: 1193-201.

12. Schlachetzki F. Herzberg M, Hölscher T et al. Transcranial ultrasound from diagnosis to early stroke treatment: part 2: prehospital neurosonography in patients with acute stroke: the Regensburg stroke mobile project. Cerebrovasc Dis 2012 33: $262-71$

13. Walter S, Kostopoulos P. Haass A et al. Diagnosis and treatment of patients with stroke in a mobile stroke unit versus in hospital: a randomised controlled trial. Lancet Neurol 2012; 11: 397-404.

14. Kostopoulos P, Walter S, Haass A et al. Mobile stroke unit for diagnosis-based triage of persons with suspected stroke. Neurology 2012; 78: 1849-52.

Mottatt 10.7. 2012, første revisjon innsendt 7.8. 2012, godkjent 16.8. 2012. Medisinsk redaktør Erlend Hem. 